\title{
Areas of Powers and Duties in Turkey Jam Metropolitan Municipalities Units on the Internal Audit Review
}

\author{
Yüksel Koçak \\ Assist. Assoc. Dr., Kafkas University, Faculty of Economics and Administrative Sciences, \\ Department of Political Science and Public Administration
}

\section{Duygu Demirol}

Res. Rates., Sakarya University, Faculty of Economics and Administrative Sciences, Department of Political Science and Public Administration ddemirol@sakarya.edu.tr

\section{Doi:10.5901/ajis.2013.v2n9p142}

\begin{abstract}
Subject of this study, we aimed to assess in terms of the functions of internal audit units of the metropolitan municipalities in Turkey. Descriptive and historical research methods were used in the study. In this context, information collected by scanning the printed and written documents in electronic form, the findings of the quantitative analysis techniques and processed. The purpose of this study, the internal audit units of metropolitan municipalities, in terms of the functions of the audit brought to the field on the basis of new insights and practices to make a comparative analysis. Within this context, the control unit of a classic Metropolitan Municipalities in Turkey "Audit Committees" to the transformation of public administration, as well as metropolitan municipalities within the framework of the European Union harmonization process of the "internal audit" konumlandırılışlarının organization units side by side, a possible "task space jam" and "confusion" questioned whether or not the road.
\end{abstract}

Keywords: Metropolitan Municipality, audit, internal audit, municipal inspection board

\section{Introduction}

Public administration is in an effort to make sense of past, present or herself in a constant quest. That is why the public administration reform is a case of maintaining the viability of each period. Starting from the 1980s, especially the new management approaches in public administration, public administration and management restructuring have affected almost every aspect has become almost a necessity. In this context, the structural and organizational change and transformation of public administration is continuing.

Public administration in the position of a part of the local authorities affected by the process of change and transformation. Trends in the world of globalization on the one hand, while on the other hand the importance of decentralization is increasing with each passing day. Which is the subject of the study of metropolitan municipalities and responsibilities of the role played in this process by the increasing importance with each passing day.

In this study, the process of change and transformation of public administration emerged as a reflection of the metropolitan municipalities, which is considered the classic sense of the internal audit unit and the inspection boards and municipalities have been analyzed. In this context, the internal audit units of the metropolitan municipalities inspection boards or jam in a conflict with each other, subject to the limits of jurisdiction order to determine the mold was left, and what measures can be taken against a possible conflict issues are discussed. The study results and recommendations of an evaluation to replace the terminated.

\section{Turkey in General Audit Metropolitan Municipalities}

Purpose of public administration, provision of goods and services is carried out on the basis of the public interest. But the control of the legal framework, whether performing service delivery possible. In this respect the activities of each administrative unit, the legal framework as well as the municipal metropolitan municipalities audited. Controls the metropolitan municipalities, the municipal councils and the inspection carried out by the internal audit units. Below before 
reviewing the monitoring control units drawn a general conceptual framework, the issue is important in terms of preparation.

\subsection{Audit and Metropolitan Municipalities in Turkey}

Control, measuring the availability of its intended purpose due to the nature and objectives of management science be considered as a complementary element.

In this context, control, management, pioneering the development of us managed to help, to increase efficiency and productivity (Eren, 2006: 256) can be defined as a means of fulfilling the function. The other approach, the audit, "the purpose and methods in the host, usually using the results of these errors and irregularities giving rise to them and those responsible for the emergence of the audited units absolute minimum the risk of error and fraud, the production of goods and services more effective, efficient and economical methods developing alternatives for the implementation of a better way to demonstrate to management that aims to lead the action "(Köse, 1999: 63) is defined as.

Conceptually, the audit, inspection, inspection, audit and control them with the different aspects of concepts such as carrying similar properties in question (Tortop et al., 2010: 113; Kocak and Aktas, 2011: 70). Audit controls only, not intended. At the same time to assist management, predicting, aims to guide it embodies. Therefore, the concept of audit, inspection, overhaul or control concepts can be said to have a more comprehensive character.

First of all phases of the audit process, and there is a certain. Planning is done primarily in order to determine the audit objectives and targets. Secondly, the activity was evaluated by monitoring and reporting. Finally, the current situation should be compared with the situation if you have to get the path of error and correction of deficiencies (Tortop et al., 2010: 117; Kuball, 1998: 57).

An audit can be classified in different ways from different angles. In general, control can be classified as internal and external management. Accordingly, management, internal audit types (internal audit), hierarchical supervision and inspection of administrative control, can be classified as internal auditor. Management types of non-audit (external audit), the political control of judicial review, the Ombudsman control, pressure groups and the public through the audit, the international audit, control types, such as effectiveness and efficiency control include (Tortop et al. 2010: 125-144).

Management control is inevitable everywhere. An unsupervised administration, impossible to achieve the expected goals. Local government units, as part of the public administration system with an effective audit can be more efficient and effective delivery of public goods and services. With this understanding, this study examined the comparative metropolitan municipalities functionality of the control units and control units, the determination of whether or not any hustle and bustle of the task studied.

Metropolitan municipalities control system in Turkey, especially in the 2000 s as restructured. The contribution of the European Union harmonization process was enacted in 2003 and 5018 on Public Financial Management and Control Law has undergone a fundamental change control mechanisms. Law control, "transparent and accountable, participatory and collaborative, open to public inspection, multi-year budgeting, strategic planning and performance-based management, result and goal-oriented, mainly local and decentralized management, the management system focused on adding value" is based on an understanding it is mentioned that (Sarı, 2009: 25).

The restructuring of local governments, 54-58 Municipal Law No. 5393 issued in 2005. Articles are in control of the municipalities. Accordingly, municipalities, internal and external audit done of the control law, compliance, performance and financial audit covered the financial transactions other than the control of the administrative proceedings shall be made by the Ministry of the Interior. Act as the purpose of the audit, "to help prevent errors, to guide the development of management and control systems, process and results of the service in accordance with pre-determined goals and objectives of the legislation, according to a measure of performance and quality standards to analyze, compare, measure, evaluate, and their results raporlandırarak announce concerned, "he stated. Metropolitan Municipality Law No. 5216 on the audit are not included in a separate regulation. In the study, the Law No. 5393 on matters relating to supervision, the Law No. 5018 and related regulations (Internal Audit Charter, the Audit Board Directive) was adopted as the legal basis.

Metropolitan municipalities control, a distinction may be subject to triple by subject (Kurtuluş transfers calmly, 2012: 236-265). The city council made by the audit, internal and external audit, control of the central government can be counted as guardianship. Administrative control units of the axis of the study; inspection committees and internal audit units creates a conflict between the powers and duties likely, the other control mechanisms are outside the scope of this study. 


\section{Administrative Control Unit Two Separate Side by Side Positioning of the Metropolitan Municipalities Turkey: Inspection Unit Internal Audit Committees and Presidents}

The one hand, the European Union within the framework of the harmonization process in Turkey "internal auditor" unit, on the other hand oluşturulmuşken lağvedilmemiş more classic control units sharing of powers and duties of these units has been adopted. Internal Audit committees and internal audit units of the metropolitan municipalities and place of the internal control system functionality is important for a qualified service delivery. These units perform similar functions in the same institution to complications of their powers and duties may from time to time.

\subsection{The Board of Inspectors}

Inspection is an important control unit of the boards of the municipalities. Inspection boards of municipalities, provincial, district and metropolitan municipalities performs inspection services (Hacıcaferoğlu, 2010:7).

More inspections carried out in the form of legality, inspector, chief inspector carried out by the Chairman of the Audit Board (Doğan, 1996: 27). As stated above, in compliance with the law currently only define control would be wrong. In addition, to guide, minimizing errors, effectiveness, and efficiency improvement, such as fitness for purpose are also functions to escape.

Regulations for municipalities in the big city inspection boards, this unit is the purpose, scope, tasks, etc.. is located. Inspection of all the municipalities of the review board regulations in the big city, the page and the time limitation of this study, due to lack of unlikely, here is an example of the Istanbul Metropolitan Municipality in terms of the Regulation on the Audit Committee investigation was appropriate.

Metropolitan Municipality, Audit, Regulation (Reg.) by (www.ibb.gov.tr, Accessed: 02/10/2013), among those who have the title of superintendent of a President, consists of enough inspectors and assistant inspectors. The Board, directly depends on the President and inspectors, inspection, audit, investigation, inspection and investigation functions, into which the name of the President (Reg. Md.5-6).

Inspection Board and the tasks performed on-site inspectors are as follows:

According to the Law on Public Financial Management and Control 5018 within the jurisdiction of the internal auditors, excluding jobs in the metropolitan municipal organization, management and control of the business and all kinds of activities and departments under the people, processes, activities related to inspection, audit, inspection and investigation to conduct their business ,

- "Business and procedures to supervise the legality and appropriateness of pre-determined criteria,"

- $\quad$ "to make a private inspection and control",

- "to establish a continuous monitoring and control mechanism",

- "of inspectors to carry out studies to provide professional development",

- "To perform other duties provided in accordance with the provisions of the legislation,"

- $\quad$ "inspection, examine and evaluate the reports and observations to the"

- "application and follow corporate policies, legislation is incompatible with service requirements and transparency; unnecessary bureaucratic procedures and records; withdrawal of service with the requirements of simplification and make recommendations for the purpose of enforcement of the new ones,"

- " auditors examining the reports and writings of view, the idea of the presidential address the deficiencies determined in terms of substantive and procedural, except for simple or factual errors, notify in writing"

- "Inspection and control their work, and deficiencies in the wrong, do not comply with the legislation works by detecting, correcting them, and the completion of the works to be better than walking and greater efficiency in the work of the officers as it deems necessary for the measures considered for those subjected to inspection and notify the Chairman of the Board together with the answers" ,

- " in the country and abroad to conduct research on issues concerning President, appointed the commission, courses, conferences, seminars, symposia and meetings, and the results of the Presidency. Participate in the preparation and implementation of in-service training programs. "

- "grow up under the auspices of the inspector to provide aids",

- "law, rules and regulations issued pursuant to the provisions to do other tasks,"

- "Investigators are responsible for their studies and prepare reports under the current legislation."

Regulation 57 Performance are given in the article. Accordingly, "the end of the annual inspection programs, inspection and control of the tasks carried out during the program, in relation to better realize the objectives of the Presidency, the development of the employees and the municipal government, the current management and control 
systems, to provide guidance to become a reliable and consistent; services, processes and legislation, the results of a pre-determined goals and objectives, performance criteria and quality standards applied to the public sector to objectively analyze, compare, measure, and evaluate evidence-based technique for reporting the results to be submitted to the President in accordance with the Board shall be submitted to the Chair "(Reg. Md.57).

Regulation 50-53. principles and procedures of construction materials are included in the inspection. According to investigators, the Metropolitan Council with the organization and its affiliates under the management and supervision of the Presidency individuals, units and organizations denetleyebileceklerdir all kinds of services and activities. In addition, investigators on staff to issue the report on the inspection and investigation. Again, regulation, inspection book and file be kept, and four copies of the results of the inspection of a sample prepared as a criticism of the inspection authority of the unit, two samples given to the Presidency of the Board, will remain an example given in the müfettisste conducting the investigation. Following the results of the inspection and be held responsible for the fulfillment of their superiors in the unit specified.

Which is important in today's understanding of the management performance audit and control function, except that it is loaded, to guide the management, performance criteria, audit, compliance audit functions such as predetermined objectives, auditors, inspectors and other institutions working in the fulfillment by the said expected. understood.

\subsection{Head of Internal Audit Unit}

Internal audit, "an organization's business processes in order to improve and add value to these processes, an independent, objective assurance and consulting activity" is defined as (Değirmencioğlu, 2011: 36). From this definition, control today, said the administration is perceived as a consulting service provided. In this respect, therefore, the internal audit system of internal control of an organization in achieving the purpose of achieving better management emerges as an important tool in guiding.

The location of the control systems of the municipalities in the metropolitan area with the Law No. 5018, the internal audit, continues to operate under the umbrella of the Internal Audit Unit. Law No. 63 of 5018 Pursuant to the internal audit, "the resources to add value and improve the work of the public administration, economy, effectiveness and efficiency are managed according to the principles and guidance in order to assess the independent, objective assurance and consulting activity. These activities are the management and control structures, risk management and financial operations, management, and control processes to evaluate and improve the effectiveness of systematic, continuous and disciplined approach and performed in accordance with generally accepted standards. " Continuation of the same substance, internal audit done by the internal auditors, public administrations, taking into account the structure and the number of personnel directly obtaining the opinion of the Internal Audit Coordination Board will be established in the top of the head of internal audit units are connected to the master.

Law No. 64 of 5018 Article internal auditors tasks listed in the following way:

- "on the basis of objective risk analysis to assess the structure of the management and control of public authorities",

- "ensure the effective, economic and efficient use of views and making recommendations,"

- "to ex-post legal compliance audit",

- $\quad$ "the administration expenditures, financial decisions and transactions with the goals and policies, development plans, programs, and evaluate the conformity of strategic plans and performance programs",

- "financial management and control of the system to control processes and make recommendations on these issues,"

- "within the framework of the audit results to make suggestions for improvements"

- $\quad$ "Based on the findings during the inspection or investigation encountered a situation which requires notifying the highest official of the administration concerned."

As can be seen, the internal auditors, "advising", "making legal compliance audit", "do not check compliance with the objectives", "objective risk analysis and controls-based audit work" for the control of certain basic tasks, such as the institution in question. In this context, the following point must mention in particular that there is no jurisdiction to investigate the internal auditor. In case of any situation, but the institution will require the investigation of this issue of the internal auditor is obliged to inform the highest authority.

The powers and duties assigned to other areas of the internal auditors, the legal source of "Regulation on Principles and Procedures of Work of Internal Auditors" is. These regulations metropolitan municipalities located within the internal auditors, the task organizes fields. 
Law No. 65 of 5018 pursuant to Regulation issued in 2006, the number of internal auditors, public administrations, qualifications and appointment, working principles and procedures of certification and grading, and regulates other matters (Bilge and Kiracı, 2010:103).

According to the Regulation, as the scope of the internal audit activity, including public administrations and local units of overseas operations and activities within the scope of risk-based audit plans and programs, systematic, continuous and disciplined approach to the audit in accordance with auditing standards consist (Reg. Art. 6 ). Internal Audit made an edit area as the Regulation (Reg. art 7):

- "Public administration and effectiveness of the investigation and evaluation of the adequacy of the internal control system",

- $\quad$ "recommendations for the development of risk management, risk assessment and risk management methods and efficiency of the examination of the application",

- $\quad$ "ensure the effective, economic and efficient use of performance assessments aimed at providing and advising governments",

- "legislation, the activities and operations of the administration, supervision of compliance with the goals and policies",

- "accounting records and financial statements, the accuracy and reliability of the examination",

- " publicly disclosed information produced all kinds of reports, statistics and financial statements, the accuracy, reliability and timeliness"

- $\quad$ "Electronic information systems and e-government services cover the fields of management and review of the reliability of the system."

According to the regulation, internal audit, compliance audit, system audit, performance audit, financial audit and information technology audit to be composed of five sub-control type (Reg. Md.8)

Regulation of internal auditors in the third chapter of the duties, powers and responsibilities are included. Necessary to study this issue is addressed within the scope of the metropolitan municipalities in assessing the functionality of the internal audit units and audit committees is important.

13th item, the internal audit units and the number of personnel on the basis of the structure of public administration, the approval of the Internal Audit Coordination Board is installed directly onto the head of administration depending on. If you have more than 5 number of internal auditors to the Board must be notified of this. 16 of the Internal Auditor of the Edited article. Accordingly, all kinds of information on the subject of the audit, certificates and documents, asking for help employees get the audited entity, to request information in writing and orally, as required by audit activity, vehicles, equipment and other facilities to exploit, control, preventive attitudes, behaviors and actions of public administration reporting, internal among the powers of the auditor. Are obliged to comply with some of the responsibilities of internal auditors in performing their duties. Legislation to comply with the auditing standards and ethical rules, authority and capacity to receive in excess of the internal audit unit, to serve impartially and independently in the presence of blocking situations, you do not notice the internal audit unit, audit reports and evaluations, the objective being to withstand the evidence obtained during the audit protection of the confidentiality of information, are listed as the responsibilities of internal auditors.

\section{The Result: A Functional Perspective of Administrative Control Unit Task Space Jam in two separate}

Located within a public institution within the institution's own internal audit activity is basically continuing presence of two different control unit, a jam from time to time in terms of the responsibilities, powers and duties can lead to confusion.

Metropolitan municipalities to control the separation of internal and external audit is determined by law. As noted earlier, the Court and the Ministry of Internal Affairs of external audit, internal audit carried out by the internal auditors. So, how do we explain the existence of metropolitan municipalities inspection boards?

Two separate administrative duties and powers of audit remain faced with a conflict in terms of the internal audit units and audit committees to be side by side is concerned (Örenay and Süzen, 2011: 30). Metropolitan municipalities that comprises two units in the field of the supervisory jurisdiction of a local government unit pitfalls of public kurumlarındandır jam.

Internal Audit committees and internal audit units of the task areas of law that there is a conflict with the task of an evaluation of the internal auditor of the Law No. 5018, the emphasis is on two fundamental issue. Accordingly, the internal auditor's ex post audits on legal compliance and public institutions to give advice and guidance service stated that a mandate drawn border. Inspection tasks kurularının inspection and investigation is on the business and operations of the municipal audit committees should be evaluated in this context is defined (Üzmez, 2010: 21). On the other hand, 
the internal audit activity to inspection under the provisions of the applicable laws as well as regulations, "task conflict" are taken into consideration, or words "task space jam" There are also opinions that will lead to (Yaman, 2011:27).

Metropolitan municipalities in Turkey and the European Union integration process inspection boards and heads of internal audit unit was created within the framework of the audit function is carried out, both in terms of the responsibilities of the unit can be said that the functionality of the potential to cause the problem. Two units of the task areas in terms of supporting the argument that the differences, the similarities / interference / jamming areas can be listed as follows:

First it should be stated that, the metropolitan municipality marshalling duties of inspectors, "except for work within the purview of Internal Auditors", an expression of the form given. This statement audit metropolitan municipalities in terms of special functions of internal auditors, investigators show that the general duty. So, they are lined with legislative duties of internal auditors, the internal auditors other than the fulfillment of tasks means. However, as shown above, also served as investigators were encouraged to count. In contrast, the internal auditors, inspectors, inspections in which the tasks are carried out by counting arrangement şeklideki separation of powers and duties between the two units belirleyebilirdi more clearly.

In other respects the two units in the overall evaluation of the tasks enumerated in legislation, administrative actions and operations both on the audit to the audit authority, the legality of both units can do, advising both sides of the unit, as the presence of the functions of such considerations to guide, These two control unit in the form of a sequel may decide from time to time on the same subject. Therefore, the existence of metropolitan municipalities two separate administrative control unit, which is expressed on the basis of similarities, the task can be said to contain each of these areas, the risk of a jam.

In order to avoid the possible compression of a mandate as possible solutions, as stated above, the internal auditors' mandates sorted and their fulfillment in the form of outside auditors, an arrangement of controls. Thus, on the one hand while avoiding duplication of tasks between these two units, on the other hand, the legislation in its current form or in a different way, the two units, which of the possible unforeseen issues that are employed will have gained clarity.

Both as an extension of changes and transformations in the world and the European Union within the framework of Compliance Programs rapid changes and transformations in Turkish public administration is concerned. However, this process of change and transformation of public administration restructuring, implementation of a new process when performing a task that is usually protected from the old classic building be reached from the implementation of open space. This road applications, from time to time between the old and the new structure also can be converted into a struggle for authority and duties. However, in this case you need to move to a new structure disbanding the old structure put in place structures to the new powers and duties of such conflict or can avoid jams.

Metropolitan municipalities were created in connection with the Internal Auditor of the European Union harmonization process inspection boards additions to the system instead of maintaining assets of the internal audit unit directly converted to inspection boards, this is in line with the adaptation process can be considered as a different approach to the allocation of some of the new units.

Change and transformation of public administration legislation starts first. Therefore, a rapid process of reform of public administration in the 2000s, after the introduction of Turkish metropolitan municipalities as a result of change and transformation in the audit system is important to examine the reflections of the legislation. However, to put the changes occurring or likely to put in practice the results always meet the change is expected. Therefore, you should analyze concrete cases in practice, theory and practice, a transformation designed to be parallel to each other.

\section{References}

Değirmencioğlu, Yavuz, (2011). "Etkili, Ekonomik ve Verimli Tek Bir Denetim Birimi”, Denetişim Dergisi, issue:6, p.35-41.

Doğan, M. E., (1996). "Belediyelerin Denetimi", Çağdaş Yerel Yönetimler Dergisi, issue: 5, volume:5.

Ekici, B. (2007). "Kamu Yönetiminde Yeniden Yapılanma ve Denetim", Kamu Yönetimi Forumu KAYFOR IV Kuramdan Uygulamaya Bildiriler Kitabı, (Ed. A. Göktürk, M. Özfinadener ve G. Ünlü ), Muğla.

Eren, Veysel (2006). "Kamu Yönetiminde Denetim Alanındaki Gelişmeler", Marmara Üniversitesi Sosyal Bilimler Enstitüsü Hakemli Dergisi, issue:25, p.255-267.

Eren, Veysel (2001).Yeni Kamu Yönetimi Anlayışı (Büyükşehir ve İ Belediyeleri Üzerine Bir Araştırma), Basılmamış Doktora Tezi, Sakarya Üniversitesi, Sakarya.

Hacıcaferoğlu, Süleyman (2010).1. Ulusal Belediyelerde Denetim ve Beklentiler, Marmara Belediyeler Birliği ve Büyükşehir Belediye Müfettişleri Derneği Sempozyum ve Paneller Dizisi No: 1.

Kiracı, Murat ve Bilge, Semih (2010).Kamu Sektöründe İç Denetim ve İç Denetimin Başarıyla Uygulanmasında Rol Oynayan Faktörler, Ankara: Gazi Kitabevi. 
Koçak, Yüksel, Aktaş, Recep (2011). "Kamu Yönetiminde İdari Denetim: Denetimin Dönüşümü", (Ed.) Koçak, Yüksel, Çiçek, Atıl Çiçek, Kamu Yönetimi, Yönetim-Siyaset Sorunlar ve Yeniden Yapılanma, Ankara, SFS Yayınları, p.68-97.

Köse, H. Ömer (2007). "Dünyada ve Türkiye'de Yüksek Denetim”, Ankara: T.C Sayıştay 145. Kuruluş YIl Dönümü Yayınları.

Köse, H. Ömer (1999). "Denetim ve Demokrasi", Sayıştay Dergisi, (Nisan-Haziran 1999),issue:33, p.62-85.

Kubalı, Derya (1998). "Performans Denetimi, Kavram, Illkeler, Metoloji ve Uygulamalar", Ankara: T.C Sayıştay Yayınları, Cumhuriyetin 75. Yıldönümü Dizi:11.

Okur, Yaşar (2007).Türkiye'de Kamu Denetimi: Değişim Süreci ve Performans Denetimi, Nobel Yayın Dağııım.

Örenay, Hami, Süzen Yücel (2011). Kamuda Teftiş ve Denetimin Görev Çakışması ve İç Denetçilerin Soruşturma Yetkisi", Denetişim Dergisi, issue: 6, p.29-35.

Sakınç, Süreyya (2012). Yerel Yönetimler Maliyesi, Orion Kitabevi.

Sarı, Mehmet (2009). "5018 Sayılı Kamu Mali Yönetimi ve Kontrol Kanununa Göre Mahalli İdarelerde Sorumlular ve Sorumluluklar", Yerel Yönetim ve Denetim Dergisi, issue:5,volume:14, p. 25-28.

Öztekin, Ali (2005).Yönetim Bilimi, Ankara, Siyasal Kitabevi.

Şengül, Ramazan (2010). Yerel Yönetimler, Kocaeli: Umuttepe Yayınları.

Toprak, Zerrin (2006). Yerel Yönetimler, Ankara: Nobel Yayın Dağııım.

Tortop, Nuri, Aykaç, Burhan, Yayman, Hüseyin, Özer, M. Akif (2006). Mahalli İdareler, Ankara: Nobel Yayın Dağııım.

Üzmez, A, (2010). 1. Ulusal Belediyelerde Denetim ve Beklentiler, Marmara Belediyeler Birliği ve Büyükşehir Belediye Müfettişleri Derneği Sempozyum ve Paneller Dizisi No:1.

Yaman, Adem (2011). "Geleneksel Teftiş Ile İç Denetim Modelinin Fonksiyonel Açıdan Değerlendirilmesi", Denetişim Dergisi, issue:6, p.22-29.

5018 Sayll Kamu Mali Yönetimi ve Kontrol Kanunu, http://www.mevzuat.gov. tr/Metin1.Aspx?MevzuatKod=1.5.5018\&Mevzuatlliski =0\&sourceXmlSearch=\&Tur=1\&Tertip=5\&No=5018, (Erişim Tarihi: 18.02.2013).

5393 Sayllı Belediye Kanunu, http://www.mevzuat.gov.tr/Metin1.Aspx?MevzuatKod =1.5.5393\&Mevzuatlliski=0\&sourceXmlSearch=\&Tur =1\&Tertip=5\&No=5393, (Erişim Tarihi: 18.02.2013).

İstanbul Büyükşehir Belediyesi Teftiş Kurulu Yönetmeliği, http://www.ibb.gov.tr/ttr-TR/Kurumsal/Birimler/TeftisKurulu/Pages/ AnaSayfa.aspx, (Erişim Tarihi: 10.02. 2013). 